\title{
Iphigenia magnifica Ansari \& R.S. Rao (Colchicaceae) - A new distributional record to the flora of Eastern Ghats, India
}

\author{
Nagaraju Vallepu ${ }^{1}$, Mahendra Nath Mitta $^{1^{*}} \&$ W. Arisdason ${ }^{2}$ \\ ${ }^{1}$ Department of Botany, Sri Venkateswara University, Tirupati 517 502, Andhra Pradesh, India \\ ${ }^{2}$ Botanical Survey of India, Southern Regional Centre, TNAU Campus, Lawley Road, Coimbatore 641 003, Tamil Nadu, India \\ *Email: mitta.mahendranath@gmail.com
}

ARTICLE HISTORY

Received: 20 April 2021

Accepted: 04 July 2021

Available online: 31 July 2021

\section{KEYWORDS}

Iphigenia; New Record;

Seshachalam hills; Eastern Ghats
ABSTRACT

Iphigenia magnifica Ansari \& R.S. Rao (Liliales: Colchicaceae), an endemic species of Western Ghats is reported in this communication as a new distributional record for Eastern Ghats from Seshachalam hills of Eastern Ghats, Andhra Pradesh. The present communication provides description of this species along with photographs of habitat, live plant and herbarium specimen, comparison with its allied species, ecology and conservation assessment.

\section{Introduction}

Colchicaceae (Liliales) (1) are an average-sized family having about 250 species in 19 genera, and widely distributed in Africa, Asia, Australia, Europe and North America (2). Colchicaceae members are characterized by perennial herbs with underground corm or rhizome, erect stem, simple or sometimes branched or reduced to short underground portion, leaves cauline, alternate to subopposite, sessile having sheath or short petiole, flowers sessile to pedicellate, hypogynous, bisexual or unisexual, tepals usually 6 , stamens 6, gynoecium tricarpellary sometimes with 2 to 4 carpels and fruits septicidal or loculicidal capsule $(3,4)$.

Iphigenia Kunth (Colchicaceae) comprising c. 12 species, is distributed from tropical and subtropical Old World to northern Australia (2). The genus is represented by six species in India, namely $I$. indica (L.) Kunth, I. magnifica Ansari \& R.S. Rao, I. mysorensis Arekal \& S.N. Ramaswamy, I. pallida Baker, I. sahyadrica Ansari \& R.S. Rao and I. stellata Blatt., of which except $I$. indica all are endemic to India $(5,6)$. Iphigenia is characterized by having erect grass-like herbs with fibrous roots or underground fleshy corm or rhizome covered with a tunic, leaves sessile, cauline or basal, five to many, alternate, sheathing, slender, lanceolate to linear-conduplicate, flowers solitary, axillary or terminal, drooping, with leaf-like bracts, perianth lobes free, dark brown to pinkish white, spreading or reflexed, stamens 6 with either hairy or glabrous filaments, anthers with monosulcate pollen grains, stigma unifid to trifid and subglobose capsular fruits.

During the botanical explorations in various parts of Seshachalam hills, a part of Eastern Ghats in Andhra Pradesh few Iphigenia individuals were collected, which were growing in sandy gravel mixed soil and near rocky crevices in gentle sloping areas of Tirumala (Japalihanuman tirtham) and Talakona forest patches. Specimens were carefully collected along with tunicate corm and properly processed. After a critical examination of morphological features of collected plant specimens along with scrutiny of pertinent literature and matching with herbarium specimens housed at different herbaria $(\mathrm{MH}, \mathrm{CAL}$ and herbarium at Sri Venkateswara University, Tirupati) the specimens were identified as Iphigenia magnifica Ansari \& R.S. Rao, a species considered to be an endemic to the Western Ghats of Goa (7), Karnataka (8, 9) and Maharashtra (10-17).

Hitherto, only two species of Iphigenia (I. indica and $I$. mysorensis) have been reported from Eastern Ghats (18) and the state of Andhra Pradesh (19). This species with spectacular brownish purple flower is neither reported from Eastern Ghats (18) nor from Andhra Pradesh (19). It is also not included in the recently published book on the flowering plants of Chittoor district (20). Therefore, the present collection of I. magnifica from Seshachalam hills, is reported here as a new record to the flora of Eastern Ghats as 


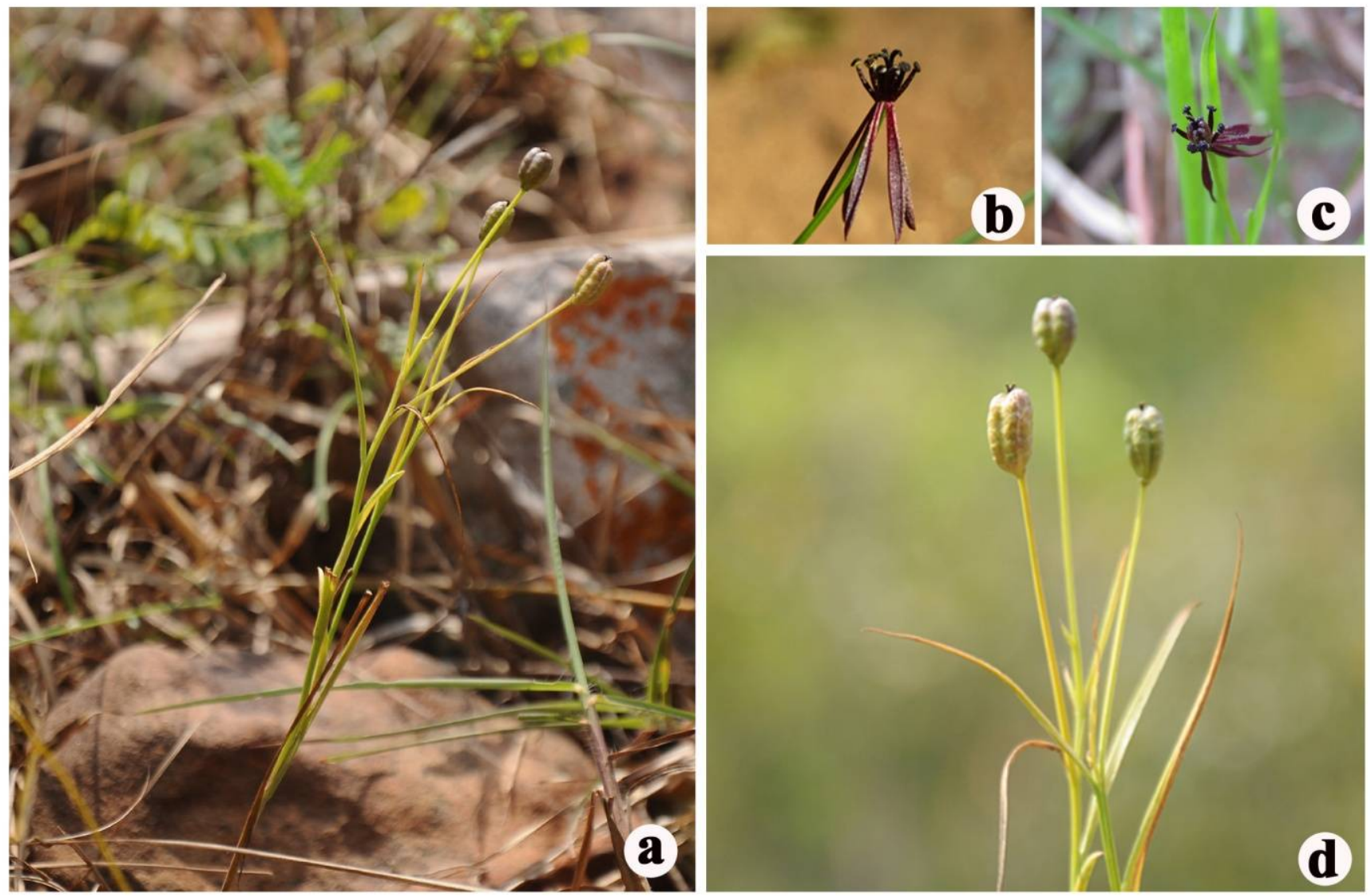

Fig. 1. Iphigenia magnifica Ansari \& R.S. Rao : a. Habit; b. Flower; c. Top-view of flower; d. Plant with matured capsules.
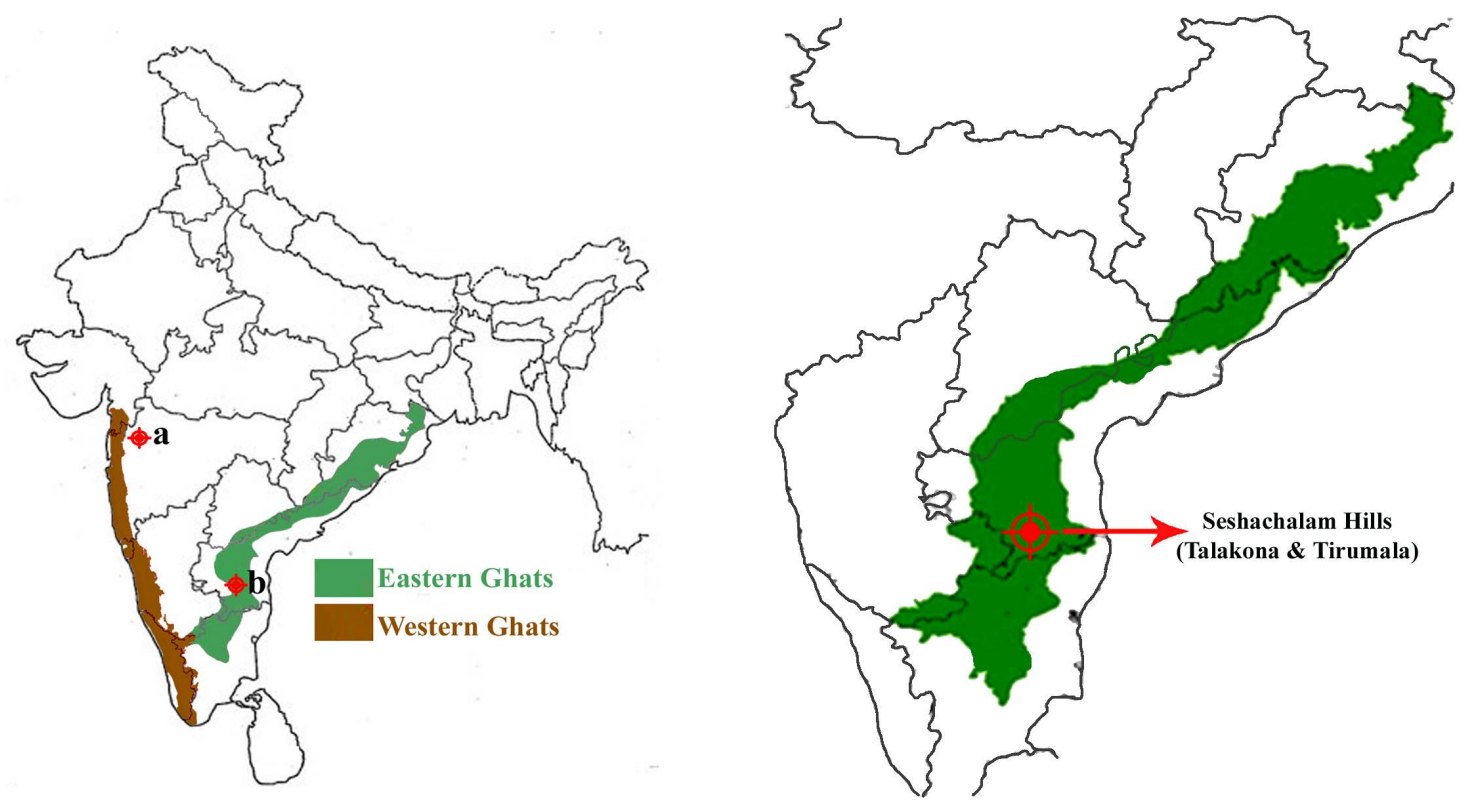

Fig. 2. Type locality of Iphigenia magnifica in Maharashtra and the place of present collection of the species from Seshachalam hills (Talakona and Tirumala) in Eastern Ghats of Andhra Pradesh.

well as to the state of Andhra Pradesh with brief description, photographs of live plants (Fig. 1) and a map showing the distribution of I. magnifica, both in Western and Eastern Ghats (Fig. 2). A voucher specimen (SVUTY-3521, (Fig. 3) of the present collection is deposited in the herbarium of Department of Botany, Sri Venkateswara University, Tirupati, for future reference. Furthermore, the morphological characters of Iphigenia magnifica are compared with its closely allied species, $I$. indica and $I$. mysorensis (Table 1).

\section{Taxonomic treatment}

Iphigenia magnifica Ansari \& R.S. Rao, Bull. Bot. Surv. India 20 (1-4): 162, pl. 1. 1979; Lakshmin. in B.D. Sharma et al., Fl. Maharashtra, Monocotyledons: 139. 1996; Lakshmin. \& V.P. Prasad in Lakshmin. et al., Fl. Karnataka 3: 317. 2019. Fig. 1. 
Table 1. Comparison of morphological characters between Iphigenia magnifica and its closely allied species, I. indica and I. mysorensis.

\begin{tabular}{|c|c|c|c|}
\hline Characters & I. indica (L.) Kunth & I. mysorensis Arekal \& S.N. Ramaswamy & I. magnifica Ansari \& R.S. Rao \\
\hline Habitat & Grasslands and plains & Marshy grasslands with small-sized gravel & Well-drained soil on gentle hillslopes \\
\hline Plant height & $8-15 \mathrm{~cm}$ & $15-20 \mathrm{~cm}$ & $15-40 \mathrm{~cm}$ \\
\hline Stem & Not branched & Not branched & Branched \\
\hline Leaves & Linear-lanceolate, $15-18 \times 0.5-1 \mathrm{~cm}$ & Acicular, $10-12 \times 0.4-0.8 \mathrm{~cm}$ & Linear-lanceolate, $20-25 \times 0.5-0.7 \mathrm{~cm}$ \\
\hline Perianth lobes & $\begin{array}{l}\text { Linear, dark brown when young, } \\
\text { brown to light green when mature }\end{array}$ & $\begin{array}{l}\text { Filiform, dark brown, except light green basal } \\
\text { portion }\end{array}$ & $\begin{array}{l}\text { Elliptic-linear, dark brown or } \\
\text { brownish purple }\end{array}$ \\
\hline Filaments & c. $4 \mathrm{~mm}$ long, hairy & c. $2 \mathrm{~mm}$ long, glabrous & 3-5 mm long, glabrous \\
\hline Anthers & Bean-shaped & Inverted heart-shaped & Bean-shaped \\
\hline Capsules & $1-2 \times 0.6-0.8 \mathrm{~cm}$ & $0.8-1 \times 0.4-0.8 \mathrm{~cm}$ & $1-1.2 \times 0.9-1.1 \mathrm{~cm}$ \\
\hline
\end{tabular}
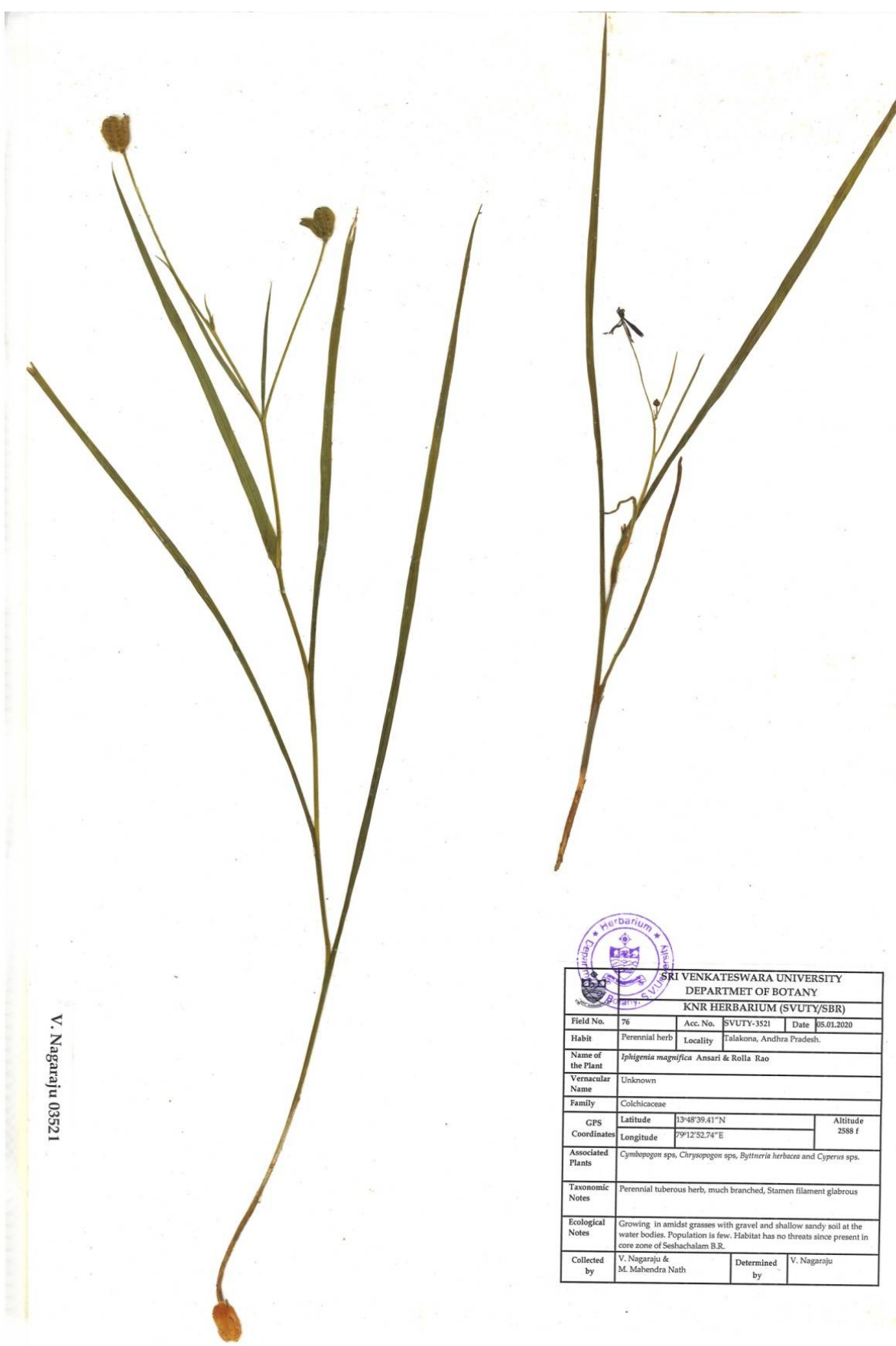

Fig. 3. Voucher specimen of Iphigenia magnifica housed in the herbarium of Department of Botany at Sri Venkateswara University, Tirupati.

Perennial herb, erect, c. $40 \mathrm{~cm}$ high; corms subglobose, 1-2 cm across, tunicate, with a delicate short neck covered with tunics. Leaves sessile, basal and cauline, alternate, 4-8, linear-lanceolate, 20-25 $\times$ $0.5-0.7 \mathrm{~cm}$, sheathing at base, acute at apex. Racemes 4-6-flowered; pedicels 6-9 cm long, with ridges and grooves, green or yellowish green; bracts linear or linear-lanceolate, 3-5 $\times 0.1-0.2 \mathrm{~cm}$, leafy. Perianth lobes 6 , linear-subulate or linear-elliptic, 1-1.5 × 0.1$0.2 \mathrm{~cm}$, acute at apex, shiny, spreading-incurved 
/reflexed, dark brown or brownish purple. Stamens 6 , 4-7 mm long; filaments 3-5 mm long, glabrous; anthers oblong or oblong-ovate, $1-2 \times c .1 \mathrm{~mm}$, dark brown. Ovary oblong-obovoid, 2-4 mm long, greenish; stigma trifid. Capsules loculicidal, oblong-obovoid, 1$1.2 \times 0.9-1.1 \mathrm{~cm}$, with somewhat rugose surface, green, turning yellowish green to brown when mature, 3valved, 3-loculed, dried stigmatic lobes persistent until capsule dehisces; seeds many, subglobose, 2-3 mm across, brown.

\section{Phenology}

\section{December-February.}

\section{Habitat and Ecology}

This species found copiously in shaded and open canopy grasslands with gravel, well-drained shallow sandy soil and near water bodies on gentle slopes of rock crevices at Talakona and 'Japalihanuman tirtham' in Tirumala, which are a part of Seshachalam hill ranges in Andhra Pradesh, at elevations ranging from 720 to $910 \mathrm{~m}$. Population is scarce. It is found growing in association with Cymbopogon spp., Chrysopogon spp., Byttneria herbacea Roxb. and Cyperus spp.

\section{Distribution}

INDIA: Endemic to Western Ghats of Karnataka, Goa and Maharashtra and Eastern Ghats of Andhra Pradesh (reported here).

\section{Specimens examined}

INDIA, Andhra Pradesh, Eastern Ghats, Seshachalam hills, 13048'39.41” N, 79012'52.74” E, 788 m, Talakona, 05.01.2020, V. Nagaraju \& M. Mahendra Nath SVUTY03521; Japalihanuman tirtham (Tirumala), 13041'59.98” N, 79020'22.05” E, $891 \mathrm{~m}, 04.01 .2020$, V. Nagaraju \& M. Mahendra Nath SVUTY-3829 (Herbarium, Department of Botany, Sri Venkateswara University, Tirupati).

\section{Conservation Assessment}

Previous workers $(5-7,21)$ reported I. magnifica as an endemic and vulnerable species confined to the northern Western Ghats. During the explorations in Seshachalam hills it is observed that the subpopulation of this species growing in grassland microhabitats, near rocky patches, is in stable condition. The Extent of Occurrence (EOO) and Area of Occupancy (AOO) of this species in Seshachalam hills were calculated using GeoCAT (Geospatial Conservation Assessment Tool): EOO: $8.240 \mathrm{~km}^{2}$ and AOO: $9.795 \mathrm{~km}^{2}$. However, as a thorough exploration is essential to assess the exact native range of distribution, population size and number of matured individuals of this species in the entire Eastern Ghats hill ranges, the status of this species is provisionally assessed here as Data Deficient following IUCN Categories and Criteria Version 3.1 (22). It is suggested to conserve and protect the ecologically sensitive areas in Seshachalam hills, where such habitatspecific species inhabit. It is also important to conserve this small population of this species in the region as such ecologically sensitive species exhibit narrow seasonality and highly restricted distribution ranges.

\section{Acknowledgements}

Authors express sincere gratitude to the Department of Botany, Sri Venkateswara University, Tirupati for providing necessary research facilities and housing the herbarium specimens. Authors are also thankful to the Director, Botanical Survey of India (BSI), Kolkata and the Head of Office of Central National Herbarium, BSI, Howrah and Madras Herbarium, BSI, Southern Regional Centre, Coimbatore for providing permission to consult the herbarium.

\section{Conflict of interests}

Authors do not have any conflict of interests to declare.

\section{References}

1. APG IV. An update of the Angiosperm Phylogeny Group classification for the orders and families of flowering plants: APG IV. Botanical Journal of the Linnean Society. 2016;181:1-20. https://doi.org/10.1111/boj.12385

2. POWO. 2021. Plants of the World Online. Available at http://www.plantsoftheworldonline.org

3. Vinnersten A, Manning J. A new classification of Colchicaceae. Taxon. 2007;56(1):171-78. https://doi.org/10.2307/25065748

4. Nordenstam B. Colchicaceae. In: Flowering Plants: Monocotyledons. Springer, Berlin, Heidelberg. 1998. pp. 175-85. https://doi.org/10.1007/978-3-662-03533-7_24

5. Lekhak MM, Surveswaran S, Yadav SR. Generic identity of Camptorrhiza indica (Colchicaceae) based on cytogenetics and molecular phylogenetics. Journal of Systematics and Evolution. 2015;54(1):75-82._https://doi.org/10.1111/jse.12165

6. Singh P, Karthigeyan K, Lakshminarasimhan P, Dash SS Endemic Vascular Plants of India. Botanical Survey of India, Kolkata. 2015.

7. Singh RK. Endemic angiosperms of Goa state, India. Indian Journal of Forestry. 2016;39(4):385-99.

8. Lakshminarasimhan P, Prasad VP. Liliacae. In: Lakshminarasimhan P, Dash SS, Singh P, Singh NP, Rao MKV, Rao PSN (eds.), Flora of Karnataka. Vol. 3 (Monocotyledons). Botanical Survey of India, Kolkata. 2019. pp. 298-323.

9. Ansari MY, Rao RS. Two new species of the genus, Iphigenia Kunth (Liliaceae) from Western Ghats (India). Bulletin of the Botanical Survey of India. 1979;20(4):162-64.

10. Lakshminarasimhan P. Liliaceae. In: Sharma BD, Karthikeyan S, Singh NP. (eds.), Flora of Maharashtra State. Monocotyledones. Botanical Survey of India, Calcutta. 1996. pp. 114-43.

11. Gaikwad S, Gore R, Garad K. Additions to the flora of Marathwada region of Maharashtra, India. Journal of Threatened Taxa. 2012;4(4):2515-23. https://doi.org/10.11609/JoTT.o2835.2515-23

12. Gaikwad S, Gore R, Garad K, Gaikwad S, Mulani R. Geophytes of northern Western Ghats (Sahyadri Ranges) of India: A checklist. Check List. 2015;11(1):1-16. https://doi.org/10.15560/11.1.1543

13. Watve A. Status review of rocky plateaus in the northern Western Ghats and Konkan region of Maharashtra, India with recommendations for conservation and management. Journal of Threatened Taxa. 2013;5(5):3935-62. https://doi.org/10.11609/JoTT.03372.3935-62

14. Rahangdale SS, Rahangdale SR. Rediscovery, systematics and proposed Red List status of Ledebouria junnarensis S.S. Rahangdale and S.R. Rahangdale nom. nov. (Asparagaceae) - An endemic species from the Western Ghats, Maharashtra, India. Journal of Threatened Taxa. 2016;8(2):8421-33. https://doi.org/10.11609/jott.2167.8.2.8421-8433

15. Rahangdale SS, Rahangdale SR. Floristic diversity of Bhimashankar Wildlife Sanctuary, northern Western Ghats, 
Maharashtra, India. Journal of Threatened Taxa. 2017;9(8): 10493-527. https://doi.org/10.11609/jott.3074.9.8.10493-10527

16. Singh RK, Garg A. The translocated Kurdi Angod sacred site - A conservatory of RET plants of the Western Ghats. Current Science. 2014;106(1):11-12.

17. Kasodekar AK, Jadhav AD, Bhagat RB, Pawar RM, Gupta VS, Kadoo NY. The importance of conserving fragmented forest patches with high diversity of flowering plants in the northern Western Ghats: an example from Maharashtra, India. Journal of Threatened Taxa. 2019;11(7):13833-49. https://doi.org/10.11609/jott.3296.11.7.13833-13849

18. Pullaiah T, Karuppusamy S. Flora of Eastern Ghats. Vol. 6: Hydrocharitaceae - Cyperaceae. Regency Publications, New Delhi. 2020. pp. 80-82.

19. Pullaiah T, Chennaiah E, Rani SS. Flora of Andhra Pradesh. Vol. 5. 2nd Rev. ed. Scientific Publishers, Jodhpur. 2018. 1932 pp.

20. Chetty KM, Ramesh L, Rajalkar KM, Manipal K. Flowering plants of Chittoor District, Andhra Pradesh, India. 6th ed. Students Offset Printers, Tirupati. 2019. 405 pp.

21. Sivaraj N, Venkateswaran K, Pandravada SR, Dikshit N, Reddy MT, Rajasekharan PE, Ahlawat SP, Rao VR. Geospatial technologies for threatened medicinal plant conservation. In: Rajasekharan PE, Wani SH. (eds.), Conservation and Utilization of Threatened Medicinal Plants. Springer Nature Switzerland AG. 2020. pp. 229-76. https://doi.org/10.1007/978-3-030-39793-7

22. IUCN. IUCN Red List Categories and Criteria, Version 3.1. 2nd Ed. IUCN Red List Unit, Gland. 2012. 32 pp.

Additional information

Peer review information: Plant Science Today thanks Sectional Editor and the other anonymous reviewers for their contribution to the peer review of this work.

Reprints and permissions information is available at https://horizonepublishing.com/journals/index.php/PST/open_access_policy

Publisher's Note: Horizon e-Publishing Group remains neutral with regard to jurisdictional claims in published maps and institutional affiliations.

To cite this article: Vallepu N, Mitta M N, Arisdason W. Iphigenia magnifica Ansar \& R.S. Rao (Colchicaceae) - A new distributional record to the flora of Eastern Ghats, India. Plant Science Today. 2021;8(3):727-731. https://doi.org/10.14719/pst.2021.8.3.1221

Plant Science Today, published by Horizon e-Publishing Group, is covered by Scopus, Web of Science, BIOSIS Previews, Clarivate Analytics, etc. See https://horizonepublishing.com/journals/index.php/PST/indexing_abstracting 